University of Nebraska - Lincoln

DigitalCommons@University of Nebraska - Lincoln

\title{
Economic returns from fungicide application to control foliar fungal diseases in winter wheat
}

\author{
Stephen N. Wegulo \\ University of Nebraska-Lincoln, swegulo2@unl.edu \\ Michael V. Zwingman \\ University of Nebraska-Lincoln \\ Julie A. Breathnach \\ University of Nebraska-Lincoln \\ P. Stephen Baenziger \\ University of Nebraska-Lincoln, pbaenziger1@unl.edu
}

Follow this and additional works at: https://digitalcommons.unl.edu/plantpathpapers

Part of the Plant Pathology Commons

Wegulo, Stephen N.; Zwingman, Michael V.; Breathnach, Julie A.; and Baenziger, P. Stephen, "Economic returns from fungicide application to control foliar fungal diseases in winter wheat" (2011). Papers in Plant Pathology. 223.

https://digitalcommons.unl.edu/plantpathpapers/223

This Article is brought to you for free and open access by the Plant Pathology Department at DigitalCommons@University of Nebraska - Lincoln. It has been accepted for inclusion in Papers in Plant Pathology by an authorized administrator of DigitalCommons@University of Nebraska - Lincoln. 


\title{
Economic returns from fungicide application to control foliar fungal diseases in winter wheat
}

\author{
Stephen N. Wegulo, ${ }^{1}$ Michael V. Zwingman, ${ }^{1}$ Julie A. Breathnach, ${ }^{1}$ and P. Stephen Baenziger ${ }^{2}$ \\ 1. Department of Plant Pathology, University of Nebraska-Lincoln, Lincoln, NE 68583 \\ 2. Department of Agronomy and Horticulture, University of Nebraska-Lincoln, Lincoln, NE 68583 \\ Corresponding author - S. Wegulo, swegulo2@unl.edu
}

\begin{abstract}
Fungicides are commonly applied to control foliar fungal diseases of winter wheat in the central Great Plains of the United States and often are routinely recommended. However, economic benefits from fungicide application in winter wheat have rarely been quantified in this region. A total of eight field experiments were conducted in 2006 and 2007 in Nebraska, USA to quantify yield increases from fungicide applications to control foliar fungal diseases in winter wheat. Experiments were conducted at the same four locations (Mead, Clay Center, North Platte and Sidney) in both years. The fungicides used were azoxystrobin + propiconazole, pyraclostrobin, propiconazole, azoxystrobin and trifloxystrobin + propiconazole applied at varying rates and growth stages. Average wheat prices were calculated from data provided by the United States Department of Agriculture (USDA) Agricultural Marketing Service. Average fungicide and fungicide application costs were obtained through surveys of local retailers, chemical manufacturers and commercial applicators. These prices and costs were used to calculate net returns from fungicide treatments. The probability of a positive net return was 0.60, 1.00 and 0.80 in 2006 (dry, low disease severity), 2007 (wet, moderate to high disease severity) and both years combined, respectively. Net returns ranged from $\$-101$ ha $^{-1}$ to $\$ 172 \mathrm{ha}^{-1}$ in 2006 and from $\$ 60 \mathrm{ha}^{-1}$ to $\$ 294 \mathrm{ha}^{-1}$ in 2007 . Net returns were at least two times the total cost (\$2 return on $\$ 1$ investment) in 4 out of 60 or $6.7 \%$ of treatments in 2006 and 51 out of 60 or $85 \%$ of treatments in 2007. In 2006, the best net returns occurred at Mead and Clay Center and resulted from the treatments 1) azoxystrobin + propiconazole applied at Zadoks growth stage (GS) 31 (first node detectable) at a rate of $0.581 \mathrm{ha}^{-1}$ and 2) azoxystrobin + propiconazole applied at GS 31 at a rate of 0.581 ha- and again at GS 37 (flag leaf just visible) at the same rate. In 2007, the treatments that resulted in the best net returns were 1) azoxystrobin + propiconazole applied at GS 39 (ligule/collar of flag leaf just visible) at a rate of 1.021 ha $^{-1}, 2$ ) pyraclostrobin applied at GS 39 at a rate of $0.661 \mathrm{ha}^{-1}$, 3) propiconazole applied at GS 39 at a rate of $0.291 \mathrm{ha}^{-1}$, and 4) trifloxystrobin + propiconazole applied at GS 39 at a rate of $0.731 \mathrm{ha}^{-1}$. For the same fungicide applied at the same rate at GS 31 and GS 39 in 2007 (wet, moderate to high disease severity), the GS 39 application generally resulted in a higher net return than the GS 31 application. Averaged across treatments and locations, net returns were $\$ 6$ ha $^{-1}$ and $\$ 183$ ha $^{-1}$ in 2006 and 2007 , respectively. The results from this study indicate that foliar fungicide application to winter wheat can be profitable in years with moderate to high disease severity; however, net loss can result if fungicides are applied in years with low disease severity.
\end{abstract}

Keywords: winter wheat, foliar fungal diseases, tan spot, spot blotch, fungicides, net returns, profitability

\section{Introduction}

Winter wheat (Triticum aestivum L.) is an economically important crop in the United States and the world. In 2009, total winter wheat production in the U.S. was $4.2 \times 10^{7} \mathrm{t}$, of which the Great Plains states of Colorado, Kansas, Montana, Nebraska, Oklahoma and Texas produced approximately 50\% (NASS, 2009). Foliar diseases of winter wheat often occur at ec- onomically damaging levels in the central Great Plains of the U.S. These diseases include tan spot [Pyrenophora tritici-repentis (Died.) Drechsler] (anamorph: Drechslera tritici-repentis), spot blotch [Cochliobolus sativus (S. Ito \& Kurib.) Drechsler ex Dastur] (anamorph: Bipolaris sorokiniana), Septoria tritici blotch [Mycosphaerella graminicola (Fuckel) J. Schröt.] (anamorph: Septoria tritici), powdery mildew [Blumeria graminis (DC.) Speer f. sp. tritici emend. É.J. Marchal], leaf rust (Puccinia triticina Erikss.), and 
stripe rust (Puccinia striiformis Westend. f. sp. tritici Erikss.). Significant yield losses have been reported to be caused by these and other diseases worldwide (Rees et al., 1982; Bockus et al., 2001; Duveiller et al., 2007; Wegulo et al., 2009).

Since the development of systemic fungicides in the late 1960s, the use of fungicides in crop production has increased over the years as has the development of new chemistries (Hewitt, 1998). The benefits of fungicide usage in crop production have long been acknowledged. Ordish and Dufour (1969) noted that spraying fungicides to control crop diseases is very popular and worthwhile because often it gives returns three times the cost involved. In the United Kingdom, experiments conducted from 1978 to 1982 showed that applying fungicides to winter wheat resulted in a yield response of up to $89 \%$, and the value of the increased yield from fungicide application to cereals in 1982 was nearly double the fungicide costs (Cook and King, 1984). In Denmark, fungicide application to control powdery mildew and Septoria diseases resulted in yield increases of 400$2700 \mathrm{~kg} \mathrm{ha}^{-1}$ with margin over cost varying from $-500 \mathrm{~kg} \mathrm{ha}^{-1}$ to $2000 \mathrm{~kg} \mathrm{ha}^{-1}$ (Jørgensen et al., 2000). An economic evaluation of fungicide use in winter wheat in Sweden showed a mean net return of US\$28 ha ${ }^{-1}$ during the period 1995-2007 and \$16 ha ${ }^{-1}$ during the period 1983-2007 (Wiik and Rosenqvist, 2010).

In the U.S., various studies have demonstrated yield increases in winter wheat due to fungicide application. Wegulo et al. (2009) showed that up to $42 \%$ yield loss was prevented by applying foliar fungicides to winter wheat in Nebraska. In Kansas, Kelley (2001) found that over a period of six years, the fungicide propiconazole significantly increased winter wheat yield 77\% of the time. Vamshidhar et al. (1998), also in Kansas, demonstrated significant yield increases from fungicide application to control the disease complex of leaf rust, tan spot, and Septoria tritici blotch in winter wheat. They found that cultivar specific economic benefits were associated with improved wheat quality from fungicide treatment. In North Dakota, Ransom and McMullen (2008) showed that within an environment and averaged across winter wheat cultivars, fungicides improved yields by 5.5-44.0\%. In Arkansas, tebuconazole applied at Zadoks growth stage (GS) 37 (Zadoks et al., 1974) and propiconazole applied at GS 37 followed by triadimefon + mancozeb at GS 55 to control leaf rust and Septoria tritici blotch consistently resulted in the lowest disease severities and highest yields (Milus, 1994).

In Nebraska, the prevalence, incidence and severity of tan spot and other residue-borne diseases such as spot blotch and Septoria tritici blotch have increased over the last several decades due to a shift toward conservation tillage practices that leave crop debris on the soil surface (Watkins and Boosalis, 1994). The damage caused by these and other foliar fungal diseases has promoted the use fungicides in winter wheat production in the central Great Plains. However, the economic returns from fungicide application in winter wheat have rarely been quantified in this region. Knowledge of the returns to expect from applying fungicides to winter wheat can enable producers to make informed disease management decisions. The objective of this research was to quantify the economic returns from applying fungicides to control foliar fungal diseases in winter wheat.

\section{Materials and methods}

\subsection{Field experiments}

In autumn 2005, seed of winter wheat cv. Millennium was planted with a small plot drill at the University of Nebraska's Agricultural Research and Development Center (ARDC) near Mead (9 Oct), the South Central Agricultural Laboratory (SCAL) near Clay Center (22 Sep), the West Central Research and Extension Center (WCREC) near North Platte (21 Sep) and the High Plains Agricultural Laboratory (HPAL) near Sidney (6 Sep) (Figure 1). This cultivar was chosen because it has excellent resistance to leaf rust $(P$. triticina) and stem rust $(P$. graminis f. sp. tritici) (Baenziger et al., 2001). Hence, confounding effects

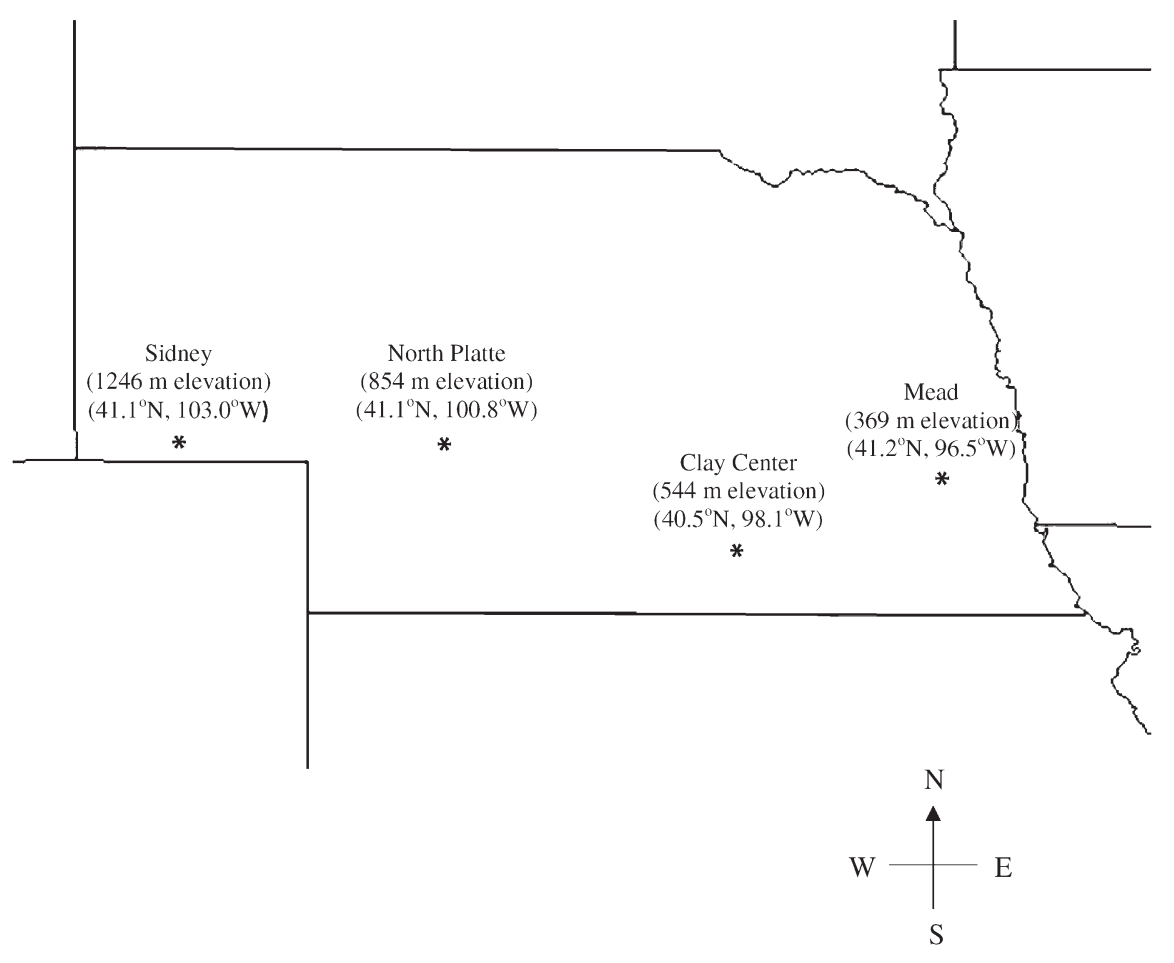

Figure 1. Map of Nebraka, USA (not to scale) showing the locations where field experiments were conducted in 2006 and 2007 to assess the economic returns from applying fungicides to control foliar fungal diseases in winter wheat cv. Millennium. 
from these diseases were minimized (Wegulo et al., 2009). Standard agronomic practices for wheat production were followed at each location. Seeding rate was 98, 84, 72 and $50 \mathrm{~kg} \mathrm{ha}^{-1}$ at Mead, Clay Center, North Platte and Sidney, respectively. Row spacing was $25.4 \mathrm{~cm}$ and plot size was $1.8 \mathrm{~m} \times 4.6 \mathrm{~m}$ at Mead, $1.2 \mathrm{~m} \times 8.2 \mathrm{~m}$ at Clay Center and Sidney and $2.1 \mathrm{~m} \times 4.6 \mathrm{~m}$ at North Platte. At each location, the plots were located within larger fields planted with cv. Millennium and measuring at least 2 ha in size. To generate different levels of disease intensity (Wegulo et al., 2009), five fungicides were each applied at GS 31 (first node on the stem detectable), GS 37 (flag leaf just visible) or GS 31 and GS 37 (Table 1). The fungicides were azoxystrobin (active ingredient comprising $7.0 \%$ of marketed product) + propiconazole (11.7\%) (Quilt, Syngenta Crop Protection, Greensboro, NC), pyraclostrobin (23.6\%) (Headline, BASF Ag Products, Research Triangle Park, NC), propiconazole (41.8\%) (Tilt, Syngenta Crop Protection, Greensboro, NC), azoxystrobin (22.9\%) (Quadris, Syngenta Crop Protection, Greensboro, NC) and trifloxystrobin $(11.4 \%)+$ propiconazole $(11.4 \%)$ (Stratego, Bayer CropScience, Research Triangle Park, NC). Treatments were arranged in randomized complete blocks with four replications.

Due to minimum or no-tillage practices and inclusion of winter wheat in crop rotation schemes, primary inoculum of $P$. tritici-repentis was provided naturally at all locations from pseudothecia on wheat straw from previous wheat crops. Inoculum of other fungal foliar pathogens such as M. graminicola, B. graminis f. sp. tritici, and P. triticina also occurred naturally. Plots were inoculated with conidia of B. sorokiniana on 2 May at Mead and Clay Center and on 5 May at Sidney and North Platte. Conidia were obtained by culturing mycelia from a single spore isolate of B. sorokiniana on V8 agar media in 9-cm-diameter Petri plates at $20{ }^{\circ} \mathrm{C}$ for $7-14$ days in continuous darkness. Sterile distilled water was added to each Petri plate and conidia were dislodged with a rubber policeman. The conidial/mycelial suspension that resulted was filtered through several layers of cheese cloth to obtain the conidial suspension. Conidial concentration was determined with a haemacytometer.

At GS 31, $30 \mathrm{~mL}$ of inoculum containing 70,000 conidia $\mathrm{ml}^{-1} \mathrm{~m}^{-2}$ were sprayed onto wheat leaves in each plot with a hand-pumped back pack sprayer. Fungicide treatments were applied $24 \mathrm{~h}$ after inoculation at each location. Fungicides were applied with a $\mathrm{CO}_{2}$-powered back pack sprayer set at $276 \mathrm{kPa}$, with a 1.2-m-wide boom and 4 Teejet \# 800-1VS nozzles spaced $0.3 \mathrm{~m}$ apart. Tan spot and spot blotch severities (\%) were visually estimated together on the flag leaf of thirty randomly selected plants per plot at growth stage GS 55 (50\% of inflorescence emerged) at Sidney and GS 60 (beginning of anthesis) at Mead, Clay Center and North Platte.

\subsection{Field experiments}

In 2007, field experiments were conducted as described in Wegulo et al. (2009). Briefly, seed of winter wheat cv. Millennium was planted with a small plot drill in autumn 2006 at the ARDC (26 Sep), SCAL (27 Sep), WCREC (17 Sep) and HPAL (13 Sep) (Figure 1). Standard agronomic practices for wheat production were followed at each location. Seeding rate was 72, 84, 72 and $50 \mathrm{~kg} \mathrm{ha}^{-1}$ at Mead, Clay Center, North Platte and Sidney, respectively. Row spacing was $25.4 \mathrm{~cm}$ and plot size was $2.4 \mathrm{~m} \times 2.4 \mathrm{~m}$ at Mead, Clay Center and North Platte and $1.2 \mathrm{~m}$ by $6.7 \mathrm{~m}$ at Sidney. At each location, the plots were located within larger fields planted with cv. Millennium and measuring at least 2 ha in size.

Inoculum of $P$. tritici-repentis and B. sorokiniana was provided as in 2006 (above). Plots were inoculated with conidia of B. sorokiniana at GS 30 (pseudostem erection) and GS 31 (first node of stem detectable). Thirty millilitres of inoculum containing 70,000 conidia $\mathrm{ml}^{-1} \mathrm{~m}^{-2}$ were sprayed onto wheat leaves in each plot with a hand-pumped back pack sprayer. Natural inoculum of $P$. tritici-repentis, M. graminicola, B. graminis $\mathrm{f}$. sp. tritici, and P. triticina was used.

Table I. Fungicide and fungicide application costs used to calculate net returns from applying fungicides to winter wheat cv. Millennium to control foliar fungal diseases at four locations ${ }^{\mathrm{a}}$ in Nebraska, USA in 2006 and 2007.

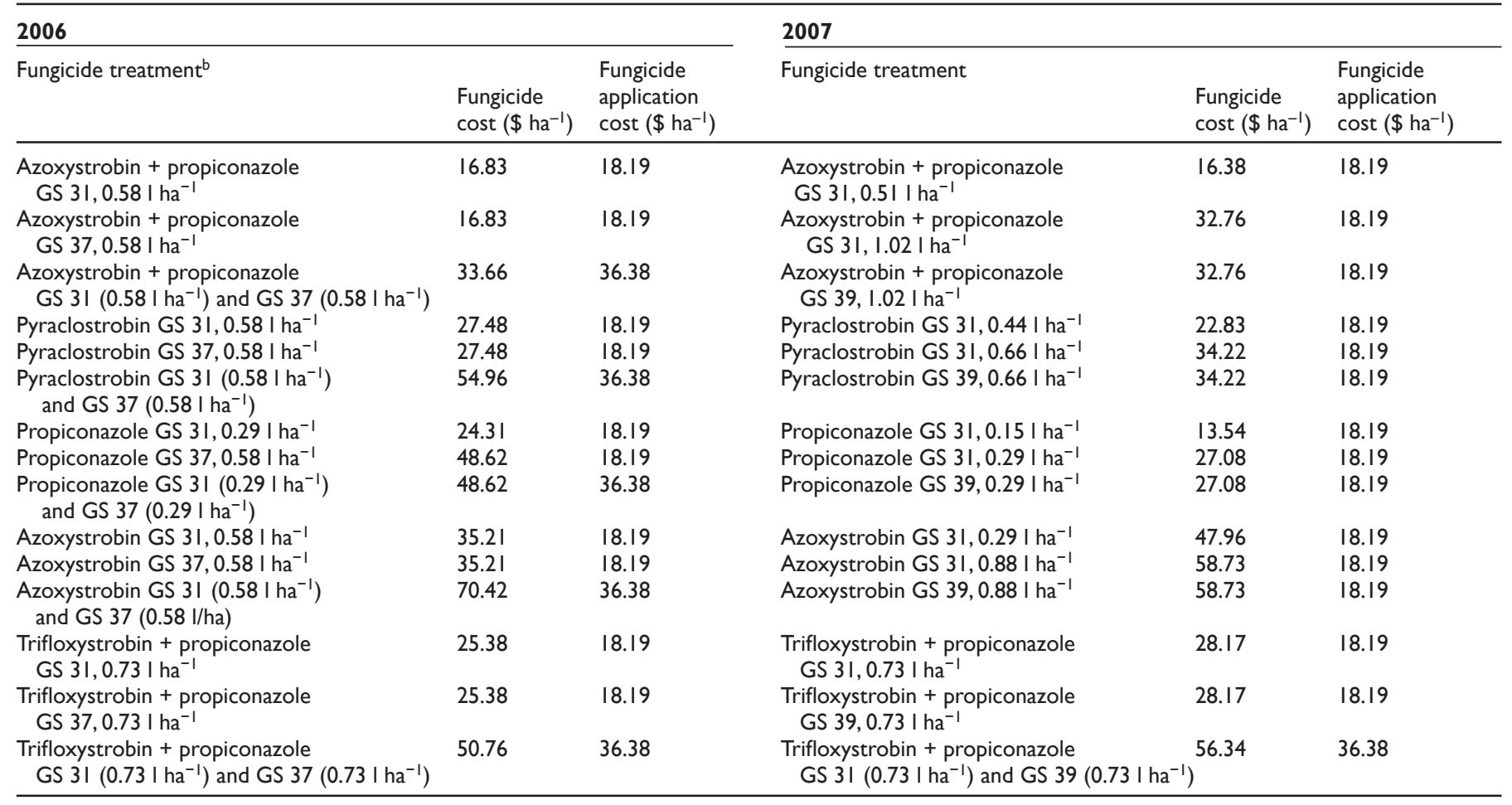

a Mead, Clay Center, North Platte, and Sidney are located, respectively, in southeastern, south central, west central, and western Nebraska.

${ }^{b}$ Fungicide (active ingredient/s), Zadoks growth stage (GS, Zadoks et al., 1974), and rate at which the fungicide was applied. 
To generate different levels of disease intensity (Wegulo et al., 2009), the fungicides azoxystrobin + propiconazole, pyraclostrobin, propiconazole, azoxystrobin and trifloxystrobin + propiconazole were applied as in 2006. Fungicide rates and the growth stages at which fungicides were applied differed slightly between 2006 and 2007 (Table 1). Tan spot and spot blotch severities (\%) were visually estimated together on the foliage of 30 plants at each of three arbitrarily selected sites per plot at GS 60 (beginning of anthesis).

\subsection{Economic analysis}

Fungicide and fungicide application costs used in economic analysis (Table 1) were obtained by surveying representatives of three chemical companies (BASF Ag Products, Bayer CropScience, and Syngenta Crop Protection), five cooperatives and three commercial aerial applicators representing the major wheat growing areas in Nebraska. All surveys were conducted in 2009 by telephone. Information provided by those surveyed was obtained from 2006 and 2007 records. Aerial application cost was used. Because aerial fungicide application is by contract between the grower and the commercial applicator, machinery and machinery maintenance costs were omitted. Adjuvant and surfactant costs were omitted because of the wide variation in their uses and costs. Average wheat prices used were $\$ 0.14 \mathrm{~kg}^{-1}$ in 2006 and $\$ 0.18 \mathrm{~kg}^{-1}$ in 2007 . They were calculated from data provided by the United States Department of Agriculture (USDA) Agricultural Marketing Service which surveys 8-12 locations daily in Nebraska. Since there are many ways for producers to market their grain, the average local prices during thirteen months were used. The months used were August prior to crop planting to August following crop harvest in 2005-2006 and 2006-2007. Net return from fungicide application was calculated as

$$
R_{\mathrm{n}}=Y_{\mathrm{i}} P-\left(F_{\mathrm{c}}+A_{\mathrm{c}}\right)
$$

where $R_{\mathrm{n}}$ is the net return from fungicide application $\left(\$ \mathrm{ha}^{-1}\right)$; $Y_{i}$ is yield increase from fungicide application $\left(\mathrm{kg} \mathrm{ha}^{-1}\right)$, obtained by subtracting the yield in the check treatment from the yield in the fungicide treatments; $P$ is the wheat price $\left(\$ \mathrm{~kg}^{-1}\right)$; $F_{c}$ is the fungicide cost $\left(\$ \mathrm{ha}^{-1}\right)$ and $A_{\mathrm{c}}$ is the fungicide application cost $\left(\$ h^{-1}\right)$. Yield increases and net returns presented in the results are means computed from replicate data. Due to rounding error, using the yield increase mean for a given treatment directly in the equation for net return may result in a net return slightly higher or lower than the net return presented in the results.

\subsection{Data analysis}

The GLM procedure of SAS version 9.2 (SAS Institute, Cary, NC) was used to analyze data. Because fungicide treatments differed slightly between 2006 and 2007, data were analyzed separately for each year. Fisher's protected least significant difference (LSD) test at $P=0.05$ (Gomez and Gomez, 1984; Steele et al., 1997) was used to compare pairs of treatment means. The probability of a positive net return was calculated by dividing the number of fungicide treatments with a net return greater than zero by the total number of treatments.

\subsection{Weather data}

Daily weather data were provided by the High Plains Regional Climate Center's Automated Weather Data Network (High Plains Regional Climate Center, School of Natural Resources, University of Nebraska-Lincoln, Lincoln, Nebraska, USA).

\section{Results}

\subsection{6}

The winter wheat crop matures earlier in eastern Nebraska (harvested in early to mid July) than in western Nebraska (harvested in mid to late July). Therefore, the grain filling period extends into July in western Nebraka. During the months of May, June, and July, the period of active flag leaf growth and grain filling, total rainfall for the three months was 13.6, 19.2, 19.5 and $10.2 \mathrm{~cm}$ at Mead, Clay Center, North Platte and Sidney, respectively. Average temperature for the three months was $21.8,22.0,21.3$ and $20.2^{\circ} \mathrm{C}$ at Mead, Clay Center, North Platte and Sidney, respectively.

Tan spot and spot blotch were observed at all four locations. Spot blotch severity was higher in research plots than in the surrounding wheat, implying that inoculation with $B$. sorokiniana was successful. Low levels of powdery mildew were observed at Mead and Clay center and low levels of leaf rust were observed at all four locations. Overall, disease severity was very low at all locations due to relatively dry weather, ranging from $1.0 \%$ at North Platte to $5.3 \%$ at Sidney (Table 2). The F-value for disease severity was significant $(P=0.0241)$ only at Clay Center. Yield was generally lower at North Platte and Sidney than that at Mead and Clay Center. It ranged from $1579 \mathrm{~kg} \mathrm{ha}^{-1}$ at Sidney to $5873 \mathrm{~kg} \mathrm{ha}^{-1}$ at Clay Center. Differences in yield (and therefore yield increase) among treatments occurred at Mead $(P=0.0004)$ and Sidney $(P<0.0001)$ (Table 2$)$.

Similarly, differences in net return among treatments occurred at Mead $(P=0.0026)$ and Sidney $(P<0.0001)$. Yield increase was negative for most treatments at North Platte and net return was negative for all treatments at this location (Table 3). At Sidney, two treatments resulted in a negative yield increase whereas six treatments resulted in a negative net return. At Mead and Clay Center, all treatments resulted in a positive yield increase. However, a negative net return resulted from one treatment at Mead and two treatments at Clay Center. The best net returns were realized at these two locations and resulted from the treatments azoxystrobin + propiconazole applied at GS 31 (first node detectable) at a rate of $0.581 \mathrm{ha}^{-1}$ and azoxystrobin + propiconazole applied at GS 31 at a rate of $0.581 \mathrm{ha}^{-1}$ and again at GS 37 (flag leaf just visible) at the same rate. The probability of a positive net return in 2006 was 0.60 . Positive net returns were generally low, ranging from $\$ 1 \mathrm{ha}^{-1}$ at Sidney to $\$ 172 \mathrm{ha}^{-1}$ at Mead (Table 3).

\subsection{7}

Disease development at all four locations was favored by higher than normal rainfall and two inoculations with conidia of $B$. sorokiniana. In addition to tan spot and spot blotch at all four locations, moderate to high levels of Fusarium head blight (scab) occurred at Mead and Clay Center and low levels of the disease occurred at North Platte. Leaf rust occurred at low levels at all locations and powdery mildew occurred at moderate to high levels at Mead and Clay Center. During the months of May, June and July, total rainfall for the 3 months was 27.9, 35.3, 38.5 and $20.8 \mathrm{~cm}$ at Mead, Clay Center, North Platte and Sidney, respectively. Average temperature for the 3 months was 21.9, 21.6, 19.8 and $19.6^{\circ} \mathrm{C}$ at Mead, Clay Center, North Platte and Sidney, respectively.

Disease severity and yield data (Table 4) have been discussed in a previous publication (Wegulo et al., 2009). Treatments differed $(P \leq 0.05)$ in yield increase and net returns at all four locations (Table 5). Yield increase and net returns were lowest at Clay Center where disease severity was highest (Table 4; Table 5) and severe levels of Fusarium head blight (FHB) occurred. Yield increase and net returns were generally of similar magnitude at Mead, North Platte and Sidney. Yield increase ranged 
from $622 \mathrm{~kg} \mathrm{ha}^{-1}$ at Clay Center to $2056 \mathrm{~kg} \mathrm{ha}^{-1}$ at Mead. Net return ranged from $\$ 60 \mathrm{ha}^{-1}$ at Clay Center to $\$ 294 \mathrm{ha}^{-1}$ at Mead and Sidney (Table 5). Treatments that resulted in the best net returns were 1) azoxystrobin + propiconazole applied at GS 39 (ligule/collar of flag leaf just visible) at a rate of $1.021 \mathrm{ha}^{-1}, 2$ ) pyraclostrobin applied at GS 39 at a rate of $\left.0.661 \mathrm{ha}^{-1}, 3\right)$ propiconazole applied at GS 39 at a rate of $0.291 \mathrm{ha}^{-1}$ and 4) trifloxys- trobin + propiconazole applied at GS 39 at a rate of $0.731 \mathrm{ha}^{-1}$ Although not always significant at $P=0.05$, a GS 39 application of a fungicide resulted in a higher net return than a GS 31 application of the same fungicide at the same rate in 18 out of 20 comparisons (Table 5). This difference was significant (LSD, $P=0.05)$ in three of four comparisons at Clay Center where disease severity was highest (Table 4; Table 5).

Table 2. Foliar disease severity and yield from experiments conducted to evaluate efficacy of fungicides in controlling foliar fungal diseases in winter wheat cv. Millennium at four locations ${ }^{a}$ in Nebraska, USA, in 2006.

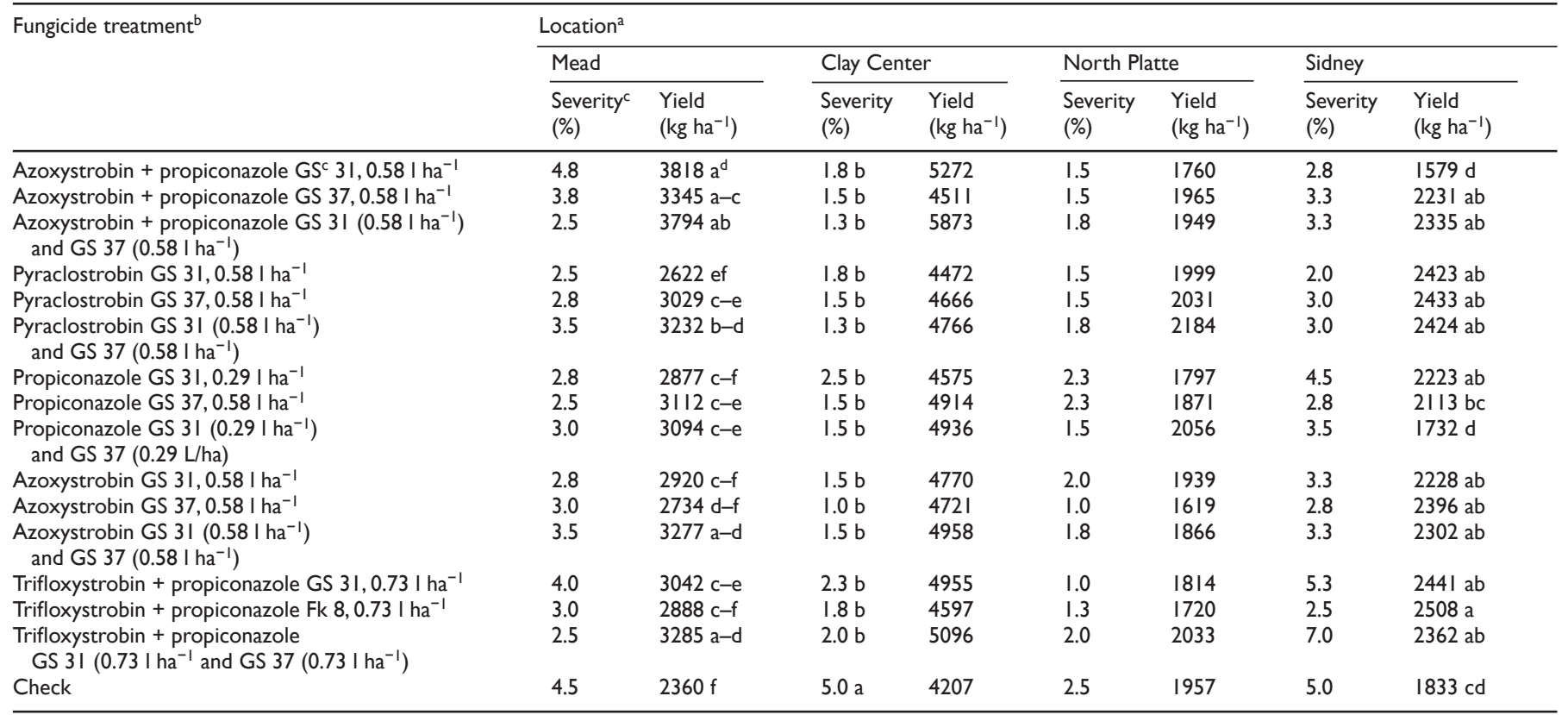

a. Mead, Clay Center, North Platte, and Sidney are located, respectively, in southeastern, south central, west central, and western Nebraska.

b. Fungicide (active ingredient/s), Zadoks growth stage (GS, Zadoks et al., 1974), and rate at which the fungicide was applied.

c. Tan spot and spot blotch severities (\%) were visually estimated together on the flag leaf of thirty randomly selected plants per plot at GS 55 ( $50 \%$ of inflorescence emerged) at Sidney and GS 60 (beginning of anthesis) at Mead, Clay Center, and North Platte. Low levels of powdery mildew and leaf rust were present at Mead and Clay Center, but not at North Platte and Sidney.

d. Means followed by the same letter within a column are not significantly different according to Fisher's protected least significant difference test at $P=0.05$.

Table 3. Yield increase and net returns from experiments conducted to assess economic returns from fungicide application to control foliar fungal diseases in winter wheat cr. Millennium at four locations in Nebraska, USA, in 2006.

\begin{tabular}{|c|c|c|c|c|c|c|c|c|}
\hline \multirow[t]{3}{*}{ Fungicide treatment ${ }^{b}$} & \multicolumn{8}{|l|}{ Location $^{\mathrm{a}}$} \\
\hline & \multicolumn{2}{|l|}{ Mead } & \multicolumn{2}{|c|}{ Clay Center } & \multicolumn{2}{|c|}{ North Platte } & \multicolumn{2}{|l|}{ Sidney } \\
\hline & $\begin{array}{l}\text { Yield } \\
\text { increase } \\
\left(\mathrm{kg} \mathrm{ha}^{-1}\right)\end{array}$ & $\begin{array}{l}\text { Net } \\
\text { return } \\
\left(\$ h^{-1}\right)\end{array}$ & $\begin{array}{l}\text { Yield } \\
\text { increase } \\
\left(\mathrm{kg} \mathrm{ha}^{-1}\right)\end{array}$ & $\begin{array}{l}\text { Net } \\
\text { return } \\
\left(\$ \mathrm{ha}^{-1}\right)\end{array}$ & $\begin{array}{l}\text { Yield } \\
\text { increase } \\
\left(\mathrm{kg} \mathrm{ha}^{-1}\right)\end{array}$ & $\begin{array}{l}\text { Net } \\
\text { return } \\
\left(\$ h^{-1}\right)\end{array}$ & $\begin{array}{l}\text { Yield } \\
\text { increase } \\
\left(\mathrm{kg} \mathrm{ha}^{-1}\right)\end{array}$ & $\begin{array}{l}\text { Net } \\
\text { return } \\
\left(\$ h^{-1}\right)\end{array}$ \\
\hline Azoxystrobin + propiconazole GS $3 \mathrm{I}, 0.58 \mathrm{I} \mathrm{ha}^{-1}$ & $1458 a^{c}$ & $172 \mathrm{a}$ & 1066 & 117 & -197 & -63 & $-254 d$ & $-7 \mid \mathrm{fg}$ \\
\hline Azoxystrobin + propiconazole GS $37,0.58 \mathrm{I} \mathrm{ha}^{-1}$ & $985 a-c$ & $105 \mathrm{a}-\mathrm{c}$ & 304 & 8 & 8 & -34 & $399 a b$ & $22 \mathrm{a}-\mathrm{e}$ \\
\hline $\begin{array}{l}\text { Azoxystrobin + propiconazole GS } 31\left(0.58 \mid \mathrm{ha}^{-1}\right) \\
\text { and GS } 37\left(0.58 \mid \mathrm{ha}^{-1}\right)\end{array}$ & $1434 \mathrm{ab}$ & $134 \mathrm{ab}$ & 1666 & 167 & -8 & -71 & $503 \mathrm{ab}$ & $\mathrm{I} a-\mathrm{e}$ \\
\hline Pyraclostrobin GS $37,0.58 \mathrm{I} \mathrm{ha}^{-1}$ & $669 c-e$ & $49 \mathrm{~cd}$ & 459 & 20 & 74 & -35 & $600 \mathrm{ab}$ & $40 \mathrm{a}-\mathrm{c}$ \\
\hline $\begin{array}{l}\text { Pyraclostrobin GS } 31\left(0.58 \mid \mathrm{ha}^{-1}\right) \\
\text { and GS } 37\left(0.58 \mid \mathrm{ha}^{-1}\right)\end{array}$ & $872 b-d$ & $33 \mathrm{~cd}$ & 560 & -12 & 227 & -59 & $592 \mathrm{ab}$ & $-7 b-e$ \\
\hline Propiconazole GS $31,0.291 \mathrm{ha}^{-1}$ & $517 c-f$ & $31 \mathrm{~cd}$ & 368 & 10 & -160 & -65 & $390 \mathrm{ab}$ & $13 \mathrm{a}-\mathrm{e}$ \\
\hline Propiconazole GS $37,0.58 \mathrm{I} \mathrm{ha}^{-1}$ & $752 c-e$ & $40 \mathrm{~cd}$ & 708 & 34 & -86 & -79 & $28 I \mathrm{bc}$ & -27 ef \\
\hline $\begin{array}{l}\text { Propiconazole GS } 31\left(0.29 \mid \mathrm{ha}^{-1}\right) \\
\text { and GS } 37\left(0.29 \mid \mathrm{ha}^{-1}\right)\end{array}$ & $734 c-e$ & $19 d$ & 730 & 19 & 99 & -71 & $-101 d$ & $-99 g$ \\
\hline Azoxystrobin GS $3 \mathrm{I}, 0.58 \mathrm{I} \mathrm{ha}^{-1}$ & $561 \mathrm{c}-\mathrm{f}$ & $26 \mathrm{~cd}$ & 563 & 27 & -19 & -56 & $395 \mathrm{ab}$ & $3 a-e$ \\
\hline Trifloxystrobin + propiconazole GS $37,0.73 \mathrm{I} \mathrm{ha}^{-1}$ & $528 c-f$ & $31 \mathrm{~cd}$ & 390 & 12 & -237 & -77 & $676 \mathrm{a}$ & $53 \mathrm{a}$ \\
\hline $\begin{array}{l}\text { Trifloxystrobin + propiconazole } \\
\qquad \text { GS } 3 \mid\left(0.73 \mid \mathrm{ha}^{-1}\right) \text { and } \mathrm{GS} 37\left(0.73 \mid \mathrm{ha}^{-1}\right)\end{array}$ & $926 \mathrm{a}-\mathrm{d}$ & $44 \mathrm{~cd}$ & 889 & 39 & 76 & -76 & $530 \mathrm{ab}$ & $-12 c-e$ \\
\hline Check & $O f$ & $0 \mathrm{~d}$ & 0 & 0 & 0 & 0 & $0 \mathrm{~cd}$ & $0 \mathrm{a}-\mathrm{e}$ \\
\hline
\end{tabular}

a. Mead, Clay Center, North Platte, and Sidney are located, respectively, in southeastern, south central, west central, and western Nebraska.

b. Fungicide (active ingredient/s), Zadoks growth stage (GS, Zadoks et al., 1974), and rate at which the fungicide was applied.

c. Means followed by the same letter within a column are not significantly different according to Fisher's protected least significant difference test at $P=0.05$. 
3.3. Effect of location on net returns and probability of a positive net return

The effect of location was highly significant in both years $(P<0.0001$, Table 6) whereas the effect of location by fungicide treatment interaction was not significant at the $5 \%$ probability level $(P>0.05)$. Overall, yield increase and therefore net returns in 2007 were much higher than in 2006. The probability of a positive net return was 1.00 in 2007 , that is, all fungicide treatments at all four locations were profitable, compared to 0.60 in 2006. Over

Table 4. Foliar disease severity and yield from experiments conducted to evaluate efficacy of fungicides in controlling foliar fungal diseases in winter wheat cv. Millennium at four locations in Nebraska, USA, in 2007. ${ }^{\text {a }}$

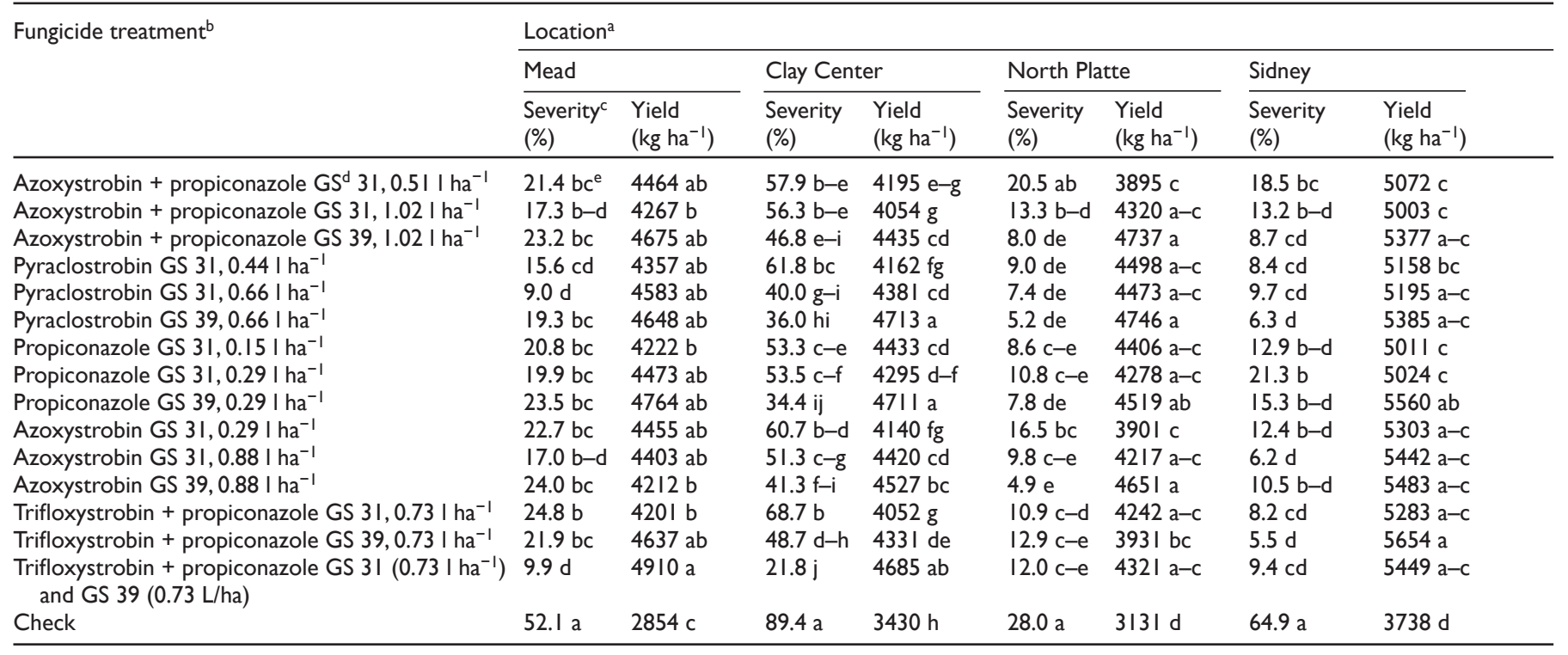

${ }^{a}$ This table is part of a larger, previously published table (Wegulo et al., 2009).

b Mead, Clay Center, North Platte, and Sidney are located, respectively, in southeastern, south central, west central, and western Nebraska.

c Fungicide (active ingredient/s), Zadoks growth stage (GS, Zadoks et al., 1974), and rate at which the fungicide was applied.

${ }^{\mathrm{d}}$ Tan spot and spot blotch severities (\%) were visually estimated together on the flag leaf of thirty randomly selected plants per plot at GS 60 (beginning of anthesis) at each location. Other diseases present were Fusarium head blight (scab) at Mead, Clay Center, and North Platte; low levels of leaf rust (cv. Millennium has excellent resistance to leaf rust); and moderate levels of powdery mildew at Mead and Clay Center.Very low levels of leaf rust were present at North Platte and Sidney.

e Means followed by the same letter within a column are not significantly different according to Fisher's protected least significant difference test at $P=0.05$.

Table 5. Yield increase and net returns from experiments conducted to assess economic returns from fungicide application to control foliar fungal diseases in winter wheat cv. Millennium at four locations in Nebraska, USA in 2007.

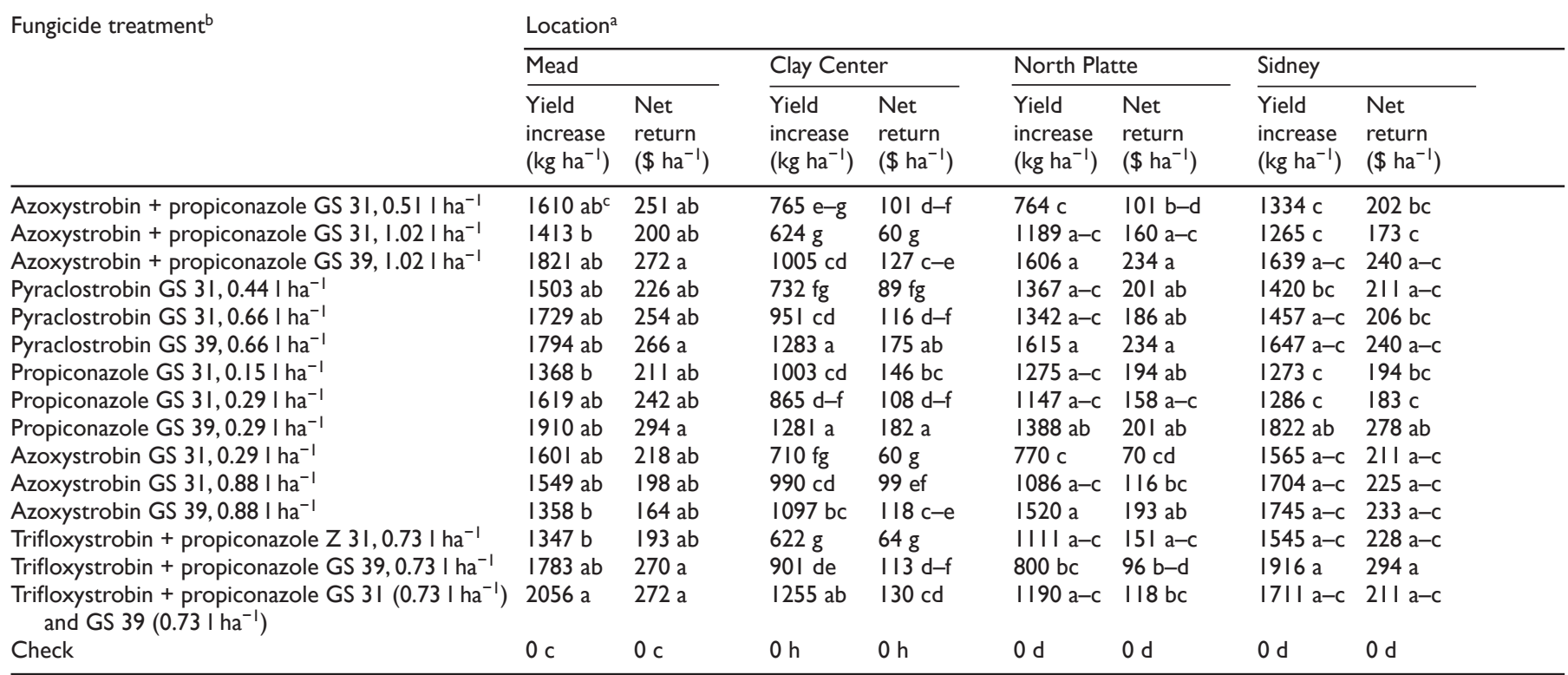

a. Mead, Clay Center, North Platte, and Sidney are located, respectively, in southeastern, south central, west central, and western Nebraska.

b. Fungicide (active ingredient/s), Zadoks growth stage (GS, Zadoks et al., 1974), and rate at which the fungicide was applied.

c. Means followed by the same letter within a column are not significantly different according to Fisher's protected least significant difference test at $P=0.05$. 
Table 6. Location and fungicide treatment effects on net returns from fungicide application to control foliar fungal diseases in winter wheat cv. Millennium in Nebraska, 2006-2007.

\begin{tabular}{lrrrrrrr}
\hline \multirow{2}{*}{ Source of variation } & d.f. & \multicolumn{2}{c}{2006} & & \multicolumn{2}{c}{2007} \\
\cline { 3 - 4 } \cline { 6 - 7 } & & Mean square & $P>F$ & & Mean square & $P>F$ \\
\hline Location (Loc) & 3 & 153,598 & $<0.0001$ & & 181887 & $<0.0001$ \\
Reps (Loc) & 12 & 43,440 & $<0.0001$ & & 40,688 & $<0.0001$ \\
Treatment (Trt) & 15 & 7994 & 0.0538 & & 45,423 & $<0.0001$ \\
Loc*Trt & 45 & 6512 & 0.0702 & & 4796 & 0.1247 \\
Pooled error & 180 & 4697 & & & 3718 & \\
Total & 255 & & & & & \\
\hline
\end{tabular}

the two years, the probability of a positive net return was 0.80 . Averaged over fungicide treatments, net returns in 2007 were $\$ 235, \$ 112, \$ 161$ and $\$ 222$ ha $^{-1}$ at Mead, Clay Center, North Platte and Sidney, respectively compared to $\$ 52, \$ 36, \$-66$ and $\$ 1 \mathrm{ha}^{-1}$ at Mead, Clay Center, North Platte and Sidney, respectively. Net returns were at least two times the total cost (\$2 return on \$1 investment) in 4 out of 60 or $6.7 \%$ of treatments in 2006 and 51 out of 60 or $85 \%$ of treatments in 2007 (data not shown).

\section{Discussion}

Results from assessment of economic returns in this study indicate that fungicide application for foliar fungal disease control in winter wheat can be profitable. However, this profitability can be variable as evidenced by the lower profitability in 2006 compared to 2007 (Table 3; Table 5). An economic evaluation of fungicide use in winter wheat in Sweden during the period from 1983 to 2007, based on results from fungicide trials in farmers' fields, similarly showed variability in net returns from year to year (Wiik and Rosenqvist, 2010). In this study, the lower profitability in 2006 can be attributed to dry weather which resulted in low disease levels. In Wisconsin, USA, Guy et al. (1989) similarly found that economic returns from fungicide application were higher in an environment with cool, moist weather which favored disease (leaf rust and Septoria tritici blotch) development compared to environments with warmer, dryer conditions which resulted in less disease. The results from this study and the study of Guy et al. (1989) indicate that the probability of a positive net return is higher when environmental conditions during the growing season favor development of moderate to severe levels of disease.

In addition to environmental conditions and, therefore, the level of disease intensity during the growing season, several factors can affect the profitability of wheat disease control with fungicides. These factors include cultural practices, cultivar resistance, fungicide application timing, fungicide and fungicide application costs and the price of wheat (Carlson and Main, 1976; Ordish and Dufour, 1969). In general, when factors that significantly reduce disease levels, such as unfavorable environmental conditions and resistant cultivars prevail, the probability of a positive net return from fungicide application is reduced.

The market price of wheat can markedly influence the profitability of applying fungicides to control foliar fungal diseases in wheat. Wiik and Rosenqvist (2010) found that doubling and tripling the grain price of winter wheat had the highest impact on the net return from fungicide application, followed by increasing fungicide cost. Wegulo (2010) compared the effects of wheat price and fungicide treatment cost (fungicide cost + application cost) on net return under varying scenarios of expected yield increase from fungicide application. At an expected yield increase of $1513 \mathrm{~kg} \mathrm{ha}^{-1}$ representing $30 \%$ of the yield potential and a fungicide treatment cost of $\$ 49 \mathrm{ha}^{-1}$, the net return was $\$ 227 \mathrm{ha}^{-1}$ at a wheat price of $\$ 0.18 \mathrm{~kg}^{-1}$ compared to $\$ 395 \mathrm{ha}^{-1}$ at a wheat price of $\$ 0.29 \mathrm{~kg}^{-1}$. Changing the treatment cost from $\$ 49 \mathrm{ha}^{-1}$ to $\$ 62 \mathrm{ha}^{-1}$ yielded a net return of $\$ 216 \mathrm{ha}^{-1}$ at a wheat price of $\$ 0.18 \mathrm{~kg}^{-1}$ compared to $\$ 383 \mathrm{ha}^{-1}$ at a wheat price of $\$ 0.29 \mathrm{~kg}^{-1}$. Therefore, although the change in wheat price was much smaller than the change in fungicide treatment cost, it had a much larger effect on net return than the change in fungicide treatment cost. This implies that even in a year with moderate to high disease levels, low wheat prices may negate the profitability of fungicide application.

The net returns from fungicide application to winter wheat in this study (\$-101 to $\$ 294 \mathrm{ha}^{-1}$ ) are similar to those reported in other studies. In Brazil, Picinini et al. (1996) reported an average net return of US\$161.94 ha ${ }^{-1}$ from applying propiconazole to control powdery mildew, leaf rust, glume blotch (Leptosphaeria nodorum (anamorph: Stagonospora nodorum)) and tan spot. In Sweden, Wiik and Rosenqvist (2010) reported an average net return of $\$ 16 \mathrm{ha}^{-1}$ from an economic evaluation of fungicide use in winter wheat over a period of 25 years. In Germany, Zschaler and Enzian (1997) compared 3000 pairs of winter wheat fungicide treatments (treated and non-treated). They found net returns ranging from $\$ 51$ to $\$ 102 \mathrm{ha}^{-1}$.

Despite the low disease severity in 2006 (Table 2), there still were yield increases from all fungicide treatments at Mead and Clay Center and some fungicide treatments at North Platte and Sidney (Table 3). Previous studies have similarly found yield increases from fungicide treatments under conditions of low disease intensity. In the United Kingdom, Jones (1994) reported yield increases in winter wheat at many sites with a low incidence of eyespot (Pseudocercosporella herpotrichoides) when prochloraz and other fungicides were applied to control the disease. In Wisconsin, USA, Guy et al. (1989) also found disease reduction and yield increases in winter wheat in environments with dry conditions and low disease intensity when fungicides were applied to control foliar diseases. It should be noted, however, that in this study the majority of the yield increases in 2006 were small and some of them resulted in negative net returns, especially at North Platte and Sidney.

The highly significant $(P<0.0001)$ effect of location on net returns (Table 6) in 2006 and 2007 implies that environment played a role in the magnitude of net returns realized. The four locations are widely separated by distance $(613 \mathrm{~km}$ between Mead and Sidney) and elevation (Figure 1) and differ significantly in average annual rainfall $(86,71,50$ and $48 \mathrm{~cm}$ annual rainfall at Mead, Clay Center, North Platte and Sidney, respectively) (High Plains Regional Climate Center, School of Natural Resources, University of Nebraska-Lincoln, Lincoln, Nebraska, USA). The effect of treatment on net returns was barely significant $(P=0.0538)$ in 2006 , but highly significant $(P<0.0001)$ in 2007 (Table 6). This can be attributed to low disease intensity in 2006 compared to moderate to high disease intensity in 2007. Location by fungicide treatment interaction was not significant in both years, implying that fungicide performance was similar at the four locations.

Net returns were at least two times the total cost ( $\$ 2$ return on $\$ 1$ investment) in 4 out of 60 or $6.7 \%$ of treatments in 2006 and 51 out of 60 or $85 \%$ of treatments in 2007 (data not shown). Growers usually would like to see a return of at least $\$ 2$ on every \$1 invested. In 2007 when disease intensity was moderate to high, causing significant losses in untreated plots, returns of up to $\$ 7$ for every $\$ 1$ invested were realized from fungicide application (data not shown). Net returns for some growers who spray routinely every year regardless of the level of disease intensity may be less than $\$ 2$ on every $\$ 1$ invested or even negative in years with little or no disease.

It is noteworthy to mention that given similar environmental conditions, fungicide and fungicide application costs and wheat prices, the actual net returns from fungicide application real- 
ized by a grower may differ from those reported in this study depending on several factors. These factors include the specific diseases present during the growing season, efficacy of the fungicide applied in controlling each of these diseases, and the level of resistance/susceptibility of the cultivar planted to each of the diseases. In this study, only one winter wheat cultivar was used and several diseases in addition to tan spot and spot blotch occurred in 2007 which likely contributed to the variation in net returns among locations. Notable among these is Fusarium head blight (FHB) which was most severe at Clay Center in 2007 and likely contributed to the low net returns in that location compared to Mead, North Platte and Sidney. All fungicides were applied before spike emergence and therefore had no effect on FHB. In addition, plots were inoculated with B. sorokiniana, and this may have resulted in higher disease intensity and hence lower fungicide efficacy than what would occur in a grower's field. Because only aerial application cost (and not ground application cost) was used and adjuvant/surfactant, machinery and machinery maintenance costs were omitted, the total costs used in the economic analysis in this study were underestimated, which may have caused the net returns to be higher than what would be realized by a grower.

In 2007 (moderate to high disease severity), a GS 39 fungicide application generally resulted in a higher net return than a GS 31 application of the same fungicide at the same rate. This was most likely due to the fact that a GS 39 application protected the flag leaf which contributes significantly to grain fill (Ali et al., 2010; Rawson et al., 1983). The residual fungicide activity from an earlier application at GS 31 would have waned by GS 39 and therefore would not have offered the same level of protection to the flag leaf as a GS 39 application. For this reason, the recommended timing of a fungicide application to winter wheat for control of foliar fungal diseases in Nebraska is between GS 39 and GS 59 .

In conclusion, this and other studies have shown that fungicide application to control foliar fungal diseases in winter wheat can be profitable. However, profitability is dependent on many factors, including weather conditions favorable to disease development, the specific diseases present, the level of disease intensity, efficacy of the fungicide applied in controlling each specific disease, fungicide and fungicide application costs and rates, fungicide application timing, cultivar resistance, cultural practices and the price of wheat. In years with low disease intensity, fungicide application can result in a net loss. All these factors should be considered when making the decision to spray.

Acknowledgments - This research was funded in part by the University of Nebraska-Lincoln Research Council and the Nebraska Wheat Board. We are indebted to Gregory Dorn, Mitchell Montgomery, David Althouse, Robert Klein, Garold Mahnken, Glen Frickel, Thomas Nightingale, Thomas McAndrew and Jeffrey Noel for logistical and technical assistance.

\section{References}

Ali et al. , 2010 • M. A. Ali, M. Hussain, M. I. Khan, Z. Ali, M. Zulkiffal, J. Anwar, W. Sabir, and M. Zeeshan, Source-sink relationship between photosynthetic organs and grain yield attributes during grain filling stage in spring wheat (Triticum aestivum), Int. J. Agric. Biol. 12 (2010), pp. 509-515.

Baenziger et al. , 2001 • P. S. Baenziger, B. Moreno-Sevilla, C. J. Peterson, D. R. Shelton, R. W. Elmore, P. T. Nordquist, R. N. Klein, D. D. Baltensperger, L. A. Nelson, D. V. McVey, J. E. Watkins, J. H. Hatchett, and G. Hein, Registration of 'Millennium' wheat, Crop Sci. 41 (2001), pp. 1367-1369.

Bockus et al. , 2001 - W. W. Bockus, J. A. Appel, R. L. Bowden, A. K. Fritz, B. S. Gill, J. Martin, R. Sears, D. L. Seifers, G. L. Brown-Guedira, and M. G. Eversmeyer, Success stories: breeding for wheat disease resistance in Kansas, Plant Dis. 85 (2001), pp. 453-461.

Carlson and Main, 1976 • G. A. Carlson and C. E. Main, Economics of disease loss management, Annu. Rev. Phytopathol. 14 (1976), pp. 381-403.

Cook and King, $1984 \cdot$ R. J. Cook and J. E. King, Loss caused by cereal diseases and the economics of fungicidal control, Plant Diseases: Infection, Damage and Loss, Blackwell Scientific Publications, Oxford (1984) pp. 237-245.

Duveiller et al. , 2007 • E. Duveiller, R. P. Singh, and J. M. Nicol, The challenges of maintaining wheat productivity: Pests, diseases, and potential epidemics, Euphytica 157 (2007), pp. 417-430.

Gomez and Gomez, 1984 - K. A. Gomez and A. A. Gomez, Statistical Procedures for Agricultural Research (second ed. ), John Wiley \& Sons, New York (1984).

Guy et al. , 1989 - S. O. Guy, E. S. Oplinger, D. W. Wiersma and C. R. Grau, Agronomic and economic response of winter wheat to foliar fungicides, J. Prod. Agric. 2 (1989), pp. 68-73.

Hewitt, 1998 - H. G. Hewitt, Fungicides in Crop Protection, CAB International, Wallingford (1998).

Jones, 1994 - D. R. Jones, Evaluation of fungicides for control of eyespot disease and yield loss relationships in winter wheat, Plant Pathol. 43 (1994), pp. 831-846.

Jørgensen et al. , 2000 • L. N. Jørgensen, K. E. Henriksen, and G. C. Nielsen, Margin over cost in disease management in winter wheat and spring barley in Denmark, Brighton Crop Protection Conference: Pests $\mathcal{E}$ Diseases, Volume 2: Proceedings of an International Conference, Brighton, UK, 13-16 November 2000 (2000) pp. 655-662.

Kelley, $2001 \cdot \mathrm{K}$. W. Kelley, Planting date and foliar fungicide effects on yield components and grain traits of winter wheat, Agron. J. 93 (2001), pp. 380-389.

Milus, 1994 - E. A. Milus, Effect of foliar fungicides on disease control, yield and test weight of soft red winter wheat, Crop Prot. 13 (1994), pp. 291-295.

NASS, 2009 - Available from: NASS, National Agricultural Statistics, USDA (2009); http://www.nass.usda.gov

Ordish and Dufour, 1969 - G. Ordish and D. Dufour, Economic bases for protection against plant diseases, Аnnu. Rev. Phytopathol. 7 (1969), pp. $31-50$.

Picinini et al. , 1996 • E. C. Picinini, J. M. Fernandes, J. C. Ignaczak, and I. Ambrosi, Economic impact due to propiconazole use on wheat, Fitopatol. Brasil. 21 (1996), pp. 362-368.

Ransom and McMullen, 2008 - J. K. Ransom and M. P. McMullen, Yield and disease control on hard winter wheat cultivars with foliar fungicides, Agron. J. 100 (2008), pp. 1130-1137.

Rawson et al. , 1983 - H. M. Rawson, J. H. Hindmarsh, R. A. Fischer, and Y. M. Stockman, Changes in leaf photosynthesis with plant ontogeny and relationships with yield per ear in wheat cultivars and 120 progeny, Aust. J. Plant Physiol. 10 (1983), pp. 503-514.

Rees et al. , 1982 • R. G. Rees, G. J. Platz, and R. J. Mayer, Yield losses in wheat from yellow spot: comparison of estimates derived from single tillers and plots, Aust. J. Agric. Res. 33 (1982), pp. 899-908.

Steele et al. , 1997 R. G. D. Steele, J. H. Torrie, and D. A. Dickey, Principles and Procedures of Statistics: A Biometrical Approach, McGraw-Hill, New York (1997).

Vamshidhar et al. , 1998 • P. Vamshidhar, T. J. Herrman, W. W. Bockus, and T. M. Loughin, Quality response of twelve hard red winter wheat cultivars to foliar disease across four locations in central Kansas, Cereal Chem. 75 (1998), pp. 94-99.

Watkins and Boosalis, 1994 - J. E. Watkins and M. G. Boosalis, Plant disease incidence as influenced by conservation tillage systems. In: P. W. Unger, Editor, Managing Agricultural Residues, Lewis Publishers, Boca Raton (1994), pp. 261-283.

Wegulo, 2010 - S. N. Wegulo, Foliar Diseases of Winter Wheat: Management with Fungicides. University of Nebraska-Lincoln Extension NebGuide G1979, 2010.

Wegulo et al. , 2009 • S. N. Wegulo, J. A. Breathnach, and P. S. Baenziger, Effect of growth stage on the relationship between tan spot and spot blotch severity and yield in winter wheat, Crop Prot. 28 (2009), pp. 696-702.

Wiik and Rosenqvist, 2010 • L. Wiik and H. Rosenqvist, The economics of fungicide use in winter wheat in southern Sweden, Crop Prot. 29 (2010), pp. 11-19.

Zschaler and Enzian, 1997 - H. Zschaler and S. Enzian, Analysis of net return resulting from different strategies of fungicide application to winter wheat from a farm economy point of view, Nachr. Bl. dt. Pfl. Schutzd. 49 (1997), pp. 74-82.

Zadoks et al. , 1974 - J. C. Zadoks, T. T. Chang, and C. F. Konzak, A decimal code for the growth stages of cereals, Weed Res. 14 (1974), pp. 415-421. 